\title{
Humor intervention in the nurse-patient interaction
}

\author{
A intervenção humor na interação enfermeiro-paciente \\ La intervención humor en la interacción enfermero-paciente
}

\section{Luis Manuel Mota Sousa' \\ ORCID: 0000-0002-9708-5690}

Cristina Maria Alves Marques-Vieira " ORCID: 0000-0002-4409-7911

Ana Vanessa Antunes "'! ORCID: 0000-0001-5784-427X

Maria de Fátima Graça Frade Iv ORCID: 0000-0002-6190-5298

Sandy Pedro Silva Severino ${ }^{v}$

ORCID: 0000-0002-5162-2980

Olga Sousa Valentim ${ }^{\text {iv }}$

ORCID: 0000-0002-2900-3972

' Universidade de Évora. Évora, Portugal. "Universidade Católica Portuguesa. Lisboa, Portugal. "'Escola Superior Egas Moniz. Caparica, Portugal. ${ }^{N}$ Escola Superior de Saúde Atlântica. Barcarena, Portugal.

${ }^{v}$ Administração Regional de Saúde Lisboa e Vale do Tejo, Portugal.

How to cite this article: Sousa LMM, Marques-Vieira CMA, Antunes AV, Frade MFG, Severino SPS, Valentim OS. Humor intervention in the nursepatient interaction. Rev Bras Enferm. 2019;72(4):1078-85. doi: http://dx.doi.org/10.1590/0034-7167-2018-0609

Corresponding Author: Luis Manuel Mota Sousa E-mail: luismmsousa@gmail.com

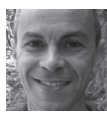

Submission: 04-09-2018

Approval: 06-03-2019

\section{ABSTRACT}

Objective: To describe the factors influencing the use of humor in nursing care, its applicability and benefits. Method: A scoping review was performed using the Arksey and O'Mally methodology. A search for articles published between 2008 and 2018 was performed using the platforms EBSCO Host, Virtual Health Library and Google Scholar. Results: From the initial 465 articles found, 17 were included for final revision. Data allowed to retrieve information on humor definition; its applicability as a nursing intervention; humor as a tool to improve nurse-patient communication and relationship; influence factors; type of humor interventions; humor benefits in health care context and; limitations and precautions of humor intervention. Conclusion: The use of humor promotes both communication and human interaction; it promotes well-being; helps $\mathrm{deal} / \mathrm{cope}$ with difficult and unpleasant situations, reduces tension, discomfort and stress; and strengthens the immune system. This intervention should be used with caution. Descriptors: Communication; Nurse-Patient Relations; Wit and Humor as Subject; Nursing; Patient Outcome Assessment.

\section{RESUMO}

Objetivo: Descrever os fatores que influenciam o uso do humor no cuidado de enfermagem, sua aplicabilidade e benefícios. Método: Revisão escopo segundo a metodologia de Arksey e O'Mally. Foram pesquisados artigos publicados entre 2008 e 2018, nas plataformas EBSCO Host, Biblioteca Virtual em Saúde e Google Académico. Resultados: Foram identificados 465 artigos e incluídos 17 destes. Foi encontrada informação sobre definição de humor; sua aplicabilidade como intervenção de enfermagem; o humor como ferramenta para melhorar a comunicação e a relação entre o enfermeiro e o paciente; fatores de influência; tipo de intervenções de humor; benefícios de humor nos cuidados de saúde e; ainda as limitações e precauções de intervenção de humor. Conclusão: $O$ humor promove a comunicação, as relações e bem-estar; ajuda a lidar com situações difíceis e desagradáveis, reduz a tensão, o desconforto e o estresse; e fortalecer o sistema imunológico. Esta intervenção deve ser usada com precaução.

Descritores: Comunicação; Relações Enfermeiro-Paciente; Senso de Humor e Humor como Assunto; Enfermagem; Avaliação de Resultados da Assistência ao Paciente.

\section{RESUMEN}

Objetivo: Describir los factores que influencian el uso del humor en el cuidado de enfermería, su aplicabilidad y beneficios. Método: Revisión de alcance según la metodología de Arksey y O'Mally. Se investigaron artículos publicados entre 2008 y 2018, en las plataformas EBSCO Host, Biblioteca Virtual en Salud y Google Académico. Resultados: Se han identificado 465 artículos e incluidos 17 de ellos. Se encontró información sobre la definición de humor; su aplicabilidad como intervención de enfermería; el humor como herramienta para mejorar la comunicación y la relación entre el enfermero y el paciente; factores de influencia; el tipo de intervenciones de humor; beneficios del humor en la atención de salud y; las limitaciones y precauciones de intervención del humor. Conclusión: El humor promueve la comunicación, las relaciones y el bienestar; ayuda a manejar situaciones difíciles y desagradables, reduce la tensión, la incomodidad y el estrés; y fortalecer el sistema inmunológico. Esta intervención debe usarse con precaución.

Descriptores: Comunicación; Relaciones Enfermera-Paciente; Ingenio y Humor como Asunto; Enfermería; Evaluación del Resultado de la Atención al Paciente. 


\section{INTRODUCTION}

The word"humor"has received many meanings throughout history. However, one of the more recent definitions refers to it as an emotional state, a state of humor that may be more or less stable, and also as an expression of feelings that can promote well-being in a person ${ }^{(1-3)}$.

The Association for Applied and Therapeutic Humor (AATH) defines "Therapeutic humor is any intervention that promotes health and wellness by stimulating a playful discovery, expression or appreciation of the absurdity or incongruity of life's situations"(4).

In Nursing Intervention Classification (NIC) this intervention is defined as the one that allows nurses to help the person to perceive, appreciate and express what is funny, entertaining or humorous, to establish relationships, relieve tension, release anger and facilitating learning or dealing with painful feelings, with the intention of promoting and maintaining health ${ }^{(5)}$.

Humor and laughter are intertwined, mutually influenced, yet they are not synonyms. Humor is an emotional response and can be translated by joy and laughter. It is a behavioral manifestation. These are influenced by a context or situation; however, they cannot be discussed separately $y^{(1-3)}$.

Studies carried out in the field of humor as a nursing intervention have demonstrated that it is beneficial for people's health and well-being ${ }^{(1-3,6-6)}$.

Given its importance, it has been integrated into nursing practice and classified nursing languages, as an intervention in $\mathrm{NIC}^{(5)}$ and as a resource and intervention in the International Classification for Nursing Practice (ICNP)(8).

However, in care, nurses do not value it ${ }^{(3,7,9)}$, as they are afraid of being unprofessional, so it is not systematized in the planning and provision of care ${ }^{(3,7)}$.

The benefits of humor in people's health and life are as follows: it promotes well-being; helps deal with difficult and unpleasant situations; brings people together by leveling their roles; helps to share feelings; enables hope; promotes relaxation; reduces tension, stress and discomfort and, increases tolerance to pain and strengthens the immune system by increasing the activity of Natural Killer cells and increasing immunoglobulin levels $s^{(1,3,9-10)}$.

\section{OBJECTIVES}

- To describe the factors influencing the use of humor in nursing care and its applicability; and,

- To identify the benefits of humor intervention in nursing care.

\section{METHODS}

\section{Ethical aspects}

Although this study did not involve people directly, ethical procedures were guaranteed.

\section{Design, study location and period}

We used the scoping review methodology. It is defined as a technique to 'map' relevant literature in the field of interest. It consists of five steps: identifying the research question; identifying relevant studies; study selection; charting the data; and collating, summarizing and reporting results ${ }^{(11)}$.

The electronic research was carried out between May and June of 2018 using the platform EBSCO Host (CINAHL Complete e MEDLINE Complete) and Biblioteca Virtual de Saúde (BVS), complemented in Google Scholar and university repositories.

\section{Study protocol}

The starting question was defined from the framework - Patient $(P)$, Concept $\left(C_{[1]}\right)$ and Context $\left(C_{[2]}{ }^{(12)}\right.$. In this sense, the research question was as following: what knowledge is produced regarding the integration of the humor intervention $\left(C_{[1]}\right)$ in the interaction $\left(C_{[2]}\right)$ nurse-person in a situation of disease $(P)$ ?

Two Boolean equations were used: [(Humor therapy) OR (Humor)] AND (review) AND (Nursing) AND (Wit and Humor as Topic) AND (Nursing). The descriptors were validated on platform of Health Science Descriptors (DeCS).

The research was conducted independently by two investigators from the research team, and the selection of the studies followed the same method, with the sequence suggested by international guidelines ${ }^{(13)}$. The results were obtained in a phased manner, from reading the title to reading the full text.

\section{Samples, inclusion and exclusion criteria}

Full text articles published in the last 10 years, in Portuguese, English, French and Spanish, that addressed the use of humor in nursing, influence factors, precautions and benefits of this intervention in the health of adults in the process of illness, were included.

\section{Analysis of the Result}

After the selection of articles, they were analyzed, and information was gathered about author(s), year of publication, study location, population (care recipient group), aims of the study, methodology and important results.

The level of evidence was classified according to the Registered Nurses' Association of Ontario's (RNAO) guidelines: la - Evidence obtained from meta-analysis or systematic review of randomized controlled studies Ib - Evidence obtained from at least one randomized controlled trial lla - Evidence obtained from at least one welldesigned controlled study without randomization llb - Evidence obtained from at least one other type of well-designed quasiexperimental study III - Evidence obtained from a well-designed non-experimental descriptive study, such as comparative study, case; IV - Evidence obtained from reports of expert committees or opinions and / or clinical experiences of respected authorities ${ }^{(14)}$.

The identification, selection, eligibility, inclusion of studies and summary chart for each article in order to systematize the relevant information was conducted independently by two investigators.

\section{RESULTS}

A total of 465 articles were identified. After reading the title, abstract and complete article, 17 articles that fulfilled the inclusion criteria were selected for final revision (Figure 1) ) $^{(2-3,6-6-7,9-10,15-25)}$. 


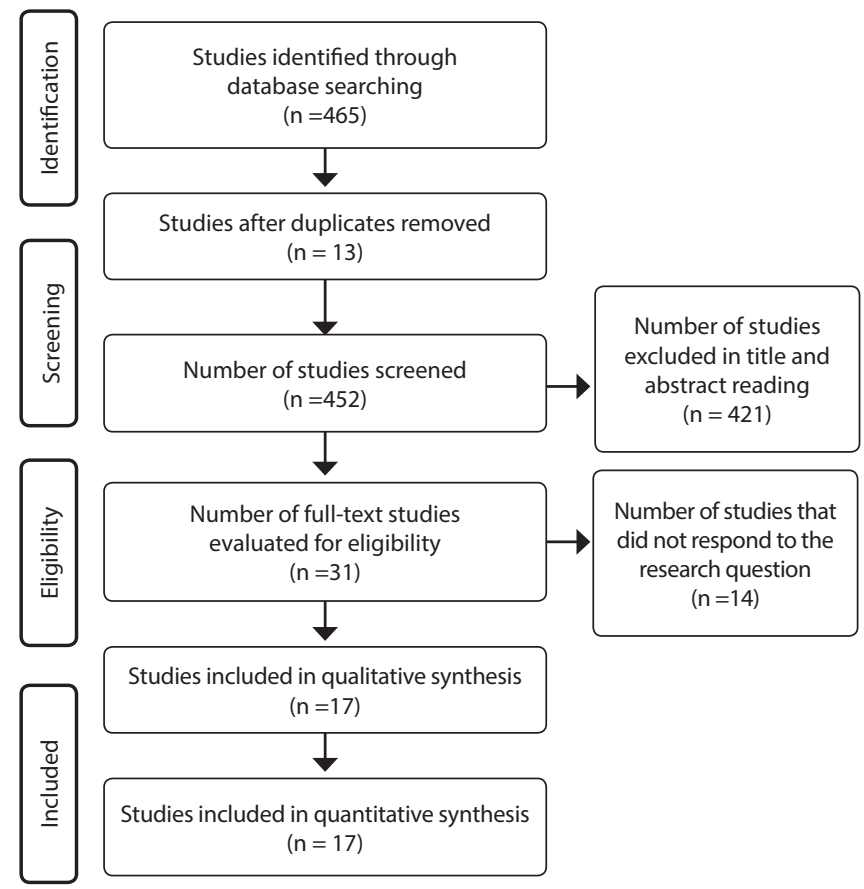

Figure 1 - Flow diagram of literature selection for scoping review

Qualitative studies ${ }^{(2,9,15-17,22)}$, mixed $^{(21)}$, narrative revisions ${ }^{(10,19,23-25)}$, integrative ${ }^{(6)}$, systematic ${ }^{(3)}$, meta-synthesis ${ }^{(7,20)}$ and concept analysis $^{(18)}$ were included.
These articles were published as follows: two in $2008^{(19,24)}$, two in $2013^{(6,18)}$, five in $2014^{(9-10,16-17,23)}$, two in $2015^{(2,15)}$, four in $2016^{(3,20-22)}$ and two in $2018^{(7,25)}$.

On what concerns country of origin, they were from Australia ${ }^{(9,15,23)}$, United States of America (USA) $)^{(17,19)}$, Spain ${ }^{(25)}$, United Kingdom (UK) $)^{(10,16,18,20,24)}$ and Portugal(2-3,6-7,21-22).

The articles present the definition of humor in nursing ${ }^{(2-3,6-7,21-22)}$ and its use in several contexts ${ }^{(3,6-7,9-10,15,20,24)}$, or in a specific context such as the perioperative period ${ }^{(19)}$, in people with dementia(17), in palliative care ${ }^{(25)}$, in people with cancer ${ }^{(16,18)}$, in the context of orthopedics ${ }^{(2,22)}$, and in people undergoing hemodialysis ${ }^{(21,23)}$.

They describe the use and function of humor as a nursing intervention $^{(3,7,9,15-16,19,21-24)}$, a communication ${ }^{(3,7,9)}$ and relation too ${ }^{(3,7,9-10)}$, actors that influence its use $\mathrm{e}^{(2-3,7,15,20-22,25)}$ and some barriers ${ }^{(3,7,20)}$, the activities of humor intervention in the interaction with the person in the process of disease and its benefits ${ }^{(3,6-7,9-10,16,18-19,21-23,25)}$, as well as, the limitations and precautions with this intervention ${ }^{(3,7,17,20,22,24-25)}$.

\section{DISCUSSION}

The discussion was organized according to the categories defined after reading the selected articles, namely: definition; use and function of humor as a nursing intervention; nursing-patient communication and improvement tool; factors influencing the use of humor; activities of the humor intervention; benefits of humor in the context of health care and; limitations and precautions of humor intervention.

Chart 1 - Characteristics of studies analyzing humor intervention in nursing

\begin{tabular}{|c|c|c|c|c|}
\hline $\begin{array}{l}\text { Author(s), } \\
\text { year, } \\
\text { location }\end{array}$ & Population & Aims & Methods & Results \\
\hline $\begin{array}{l}\text { Bennett et } \\
\text { al., 2014, } \\
\text { Australia }^{(23)} \text {. }\end{array}$ & $\begin{array}{l}11 \text { articles } \\
\text { about humor } \\
\text { on different } \\
\text { populations }\end{array}$ & $\begin{array}{l}\text { To identify the evidence } \\
\text { related to laughter } \\
\text { and humor therapy in } \\
\text { people undergoing } \\
\text { hemodialysis. }\end{array}$ & $\begin{array}{c}\text { Narrative } \\
\text { Review (NR). }\end{array}$ & $\begin{array}{l}\text { Therapeutic interventions range from humorous videos, stories, laugh } \\
\text { clowns through shrill simulated laughter and Laughter Yoga. The } \\
\text { effect of laughter and humor on depression, anxiety, pain, immunity, } \\
\text { fatigue, sleep quality, respiratory function and glucose levels may have } \\
\text { applications for the context of dialysis and requires more research. }\end{array}$ \\
\hline $\begin{array}{l}\text { Branney et } \\
\text { al., 2014, } \\
\text { United } \\
\text { Kingdom }{ }^{(16)} \text {. }\end{array}$ & $\begin{array}{l}10 \text { men with } \\
\text { penile cancer }\end{array}$ & $\begin{array}{l}\text { To explore how men } \\
\text { with penile cancer build } \\
\text { humor in relation to their } \\
\text { diagnosis and treatment. }\end{array}$ & $\begin{array}{l}\text { Qualitative. } \\
\text { Focus } \\
\text { group. } \\
\text { Nvivo } \\
\text { analysis. }\end{array}$ & $\begin{array}{l}\text { Humor helped participants to minimize their condition, which } \\
\text { meant they could laugh about the treatment consequences and } \\
\text { build a relationship with health professionals. The results suggest a } \\
\text { combination of functionalism, relief, and humor incongruity theories. } \\
\text { When appropriated, nurses should continue to use humor to build } \\
\text { a relationship with people in illness process. Jokes about sexual and } \\
\text { urinary function should be avoided. }\end{array}$ \\
\hline $\begin{array}{l}\text { Buxman, } \\
\text { 2008, United } \\
\text { States of } \\
\text { America }{ }^{(19)} \text {. }\end{array}$ & $\begin{array}{l}\text { Articles about } \\
\text { the use of } \\
\text { humor in the } \\
\text { perioperative } \\
\text { period }\end{array}$ & $\begin{array}{l}\text { To explore the use } \\
\text { of humor in the } \\
\text { perioperative context. }\end{array}$ & NR. & $\begin{array}{l}\text { Humor has multiple purposes and offers numerous benefits for both health } \\
\text { professionals and patients. } \\
\text { In the perioperative context, humor can be used to establish relationships, } \\
\text { relieve anxiety, release anger in a socially acceptable way, avoid or deny } \\
\text { painful feelings, and facilitate learning. Nurses in this context can use a } \\
\text { variety of techniques and resources to increase the use of humor. }\end{array}$ \\
\hline $\begin{array}{l}\text { Haydon et } \\
\text { al., 2015, } \\
\text { Australia }^{(15)} \text {. }\end{array}$ & 4 nurses & $\begin{array}{l}\text { To explore the experiences } \\
\text { of four nurses on the use } \\
\text { of humor in relation to } \\
\text { gender differences and } \\
\text { how it influences the } \\
\text { therapeutic relationship. }\end{array}$ & $\begin{array}{l}\text { Qualitative } \\
\text { Narrative } \\
\text { inquiry. }\end{array}$ & $\begin{array}{l}\text { The study revealed gender differences on how humor is used by } \\
\text { patients. For women, humor is often instantaneous and linked to the } \\
\text { situation. It is used to facilitate communication for others. On the other } \\
\text { hand men generate humor through stories and anecdotes. This is } \\
\text { designed to establish a sense of balanced power between the patient } \\
\text { and nurse. }\end{array}$ \\
\hline $\begin{array}{l}\text { Haydon \& } \\
\text { Riet, 2014, } \\
\text { Australia(9). }^{(9)}\end{array}$ & 4 nurses & $\begin{array}{l}\text { To report the perceptions } \\
\text { of four nurses on humor } \\
\text { initiated by patients; how } \\
\text { nurses react to patient's } \\
\text { humor in the clinical } \\
\text { setting. }\end{array}$ & $\begin{array}{l}\text { Qualitative. } \\
\text { Narrative } \\
\text { inquiry. }\end{array}$ & $\begin{array}{l}\text { Humor is a very personal concept. What a person thinks is funny does } \\
\text { not necessarily make the other smile, as it may even be painful. Humor is } \\
\text { an important communication tool for patients, as it humanizes nursing } \\
\text { care, creates a bond and opens communication channels. Humor has } \\
\text { the potential to change a patient's experience during hospitalization }\end{array}$ \\
\hline
\end{tabular}


Chart 1

\begin{tabular}{|c|c|c|c|c|}
\hline $\begin{array}{l}\text { Author(s), } \\
\text { year, } \\
\text { location }\end{array}$ & Population & Aims & Methods & Results \\
\hline $\begin{array}{l}\text { Jone \& } \\
\text { Tanay, 2016, } \\
\text { United } \\
\text { Kingdom } \\
\end{array}$ & 7 articles & $\begin{array}{l}\text { To identify studies about } \\
\text { nurses' perceptions of } \\
\text { potential barriers to the } \\
\text { use of humor in practice. }\end{array}$ & $\begin{array}{l}\text { Systematic } \\
\text { Literature } \\
\text { Review } \\
\text { (SLR) } \\
\text { Qualitative } \\
\text { studies. }\end{array}$ & $\begin{array}{l}\text { The review and thematic analysis identified five key themes: (1) } \\
\text { inadequate situations, (2) being a new or junior nurse, (3) impact on nurse } \\
\text { professionalism, (4) differences in personality, and (5) environmental } \\
\text { factors. Conclusion: the results identified nurses' perceptions about } \\
\text { possible barriers that prevent the use of humor in practice. The extent } \\
\text { to which nurses use humor is related to personality factors, but it is also } \\
\text { affected by external and social factors. The reluctance in its use in practice } \\
\text { is influenced by views that humor is not professional; with senior nurses } \\
\text { found to have a relevant role in influencing its use. }\end{array}$ \\
\hline $\begin{array}{l}\text { Liptak et al., } \\
\text { 2014, United } \\
\text { States of } \\
\text { America }{ }^{(17)}\end{array}$ & $\begin{array}{l}20 \text { people } \\
\text { with cognitive } \\
\text { impairment }\end{array}$ & $\begin{array}{l}\text { To describe humor and } \\
\text { laugh in people with } \\
\text { cognitive impairment } \\
\text { (PWCI) through a } \\
\text { caregiver focus group. }\end{array}$ & Qualitative. & $\begin{array}{l}\text { Humor and laughter were present in all four focus groups. Emerging } \\
\text { themes of humor included foolish, sarcasm and comments on the } \\
\text { difficulties of dementia. Laughter was identified in segments with } \\
\text { and without humor. Humor and laughter played a role in creating a } \\
\text { safe social environment. Some people with dementia had difficulty } \\
\text { recognizing social signs of mood }\end{array}$ \\
\hline $\begin{array}{l}\text { McCreaddie } \\
\text { Wiggins, } \\
\text { 2008, United } \\
\text { Kingdom }{ }^{(24)} \text {. }\end{array}$ & $\begin{array}{l}88 \text { articles } \\
\text { on the topic } \\
\text { humor }\end{array}$ & $\begin{array}{l}\text { To identify, analyze and } \\
\text { synthesize the humor } \\
\text { literature related to } \\
\text { health, health care and } \\
\text { nursing. }\end{array}$ & NR & $\begin{array}{l}\text { Humor in the physician-patient interaction demonstrates that its use by } \\
\text { people in the process of illness is challenging and revealing, especially } \\
\text { with regard to self-deprecating humor. Nurses should adopt a cautious } \\
\text { and evidenced-based approach for the use of humor in their work. }\end{array}$ \\
\hline $\begin{array}{l}\text { Pinna et } \\
\text { al. 2018, } \\
\text { Spain }^{(25)} \text {. }\end{array}$ & $\begin{array}{l}34 \text { articles } \\
\text { on the topic } \\
\text { humor }\end{array}$ & $\begin{array}{l}\text { To understand the } \\
\text { significance, suitability } \\
\text { and relevance of humor } \\
\text { in palliative care and } \\
\text { analyze its applicability. }\end{array}$ & $\begin{array}{c}\text { NR. } \\
\text { PROSPERO. }\end{array}$ & $\begin{array}{l}\text { Thirty-four studies were included. Five main topics were identified: (1) humor } \\
\text { definition, (2) humor use and applicability in palliative care, (3) how to use } \\
\text { humor, (4) when does not to use humor, and (5) humor before and after } \\
\text { diagnosis of terminal disease. In the palliative care context the function } \\
\text { of humor can be classified into three main topics: building relationships, } \\
\text { as it improves relations between patient and family, patient and health } \\
\text { professionals and between health professionals and families, leading to } \\
\text { bonding, developing trust and providing more relaxed relationships, reducing } \\
\text { levels of fear and distance between people, strengthening and consolidating } \\
\text { therapeutic relationships: it allows the management of conflicts through } \\
\text { communication and active listening of health professionals, being a channel } \\
\text { to discuss complex issues, such as death, giving information and transmitting } \\
\text { bad news; finally, it allows the expression of feelings, recognizing people as } \\
\text { human beings and bringing humanity to the health professional. It facilitates } \\
\text { the relationship with others, as it helps to foster the understanding of the } \\
\text { person, of others and of oneself. The physical benefits from the use of humor } \\
\text { are relaxation, pain reduction and it helps to deal with other symptoms. } \\
\text { Conclusions: humor plays an unquestionable role in palliative care, but its use } \\
\text { requires adequate training and use. }\end{array}$ \\
\hline $\begin{array}{l}\text { Santos et } \\
\text { al., 2016, } \\
\text { Portugal (22). }\end{array}$ & 11 nurses & $\begin{array}{l}\text { To identify the strategies } \\
\text { and benefits of } \\
\text { humor intervention in } \\
\text { orthopedics. }\end{array}$ & $\begin{array}{l}\text { Content } \\
\text { analysis. }\end{array}$ & $\begin{array}{l}\text { This study aims to contribute to the understanding of humor } \\
\text { intervention, namely: aspects to be taken into account in the evaluation, } \\
\text { planning and implementation of this intervention; and the main } \\
\text { benefits in the health and well-being of hospitalized people. For this } \\
\text { intervention can be used countless resources such as jokes, antics, jokes, } \\
\text { anecdotes, puns, surprises, funny situations, personal experiences, } \\
\text { comic comments, spontaneous expressions comic, music and movies. } \\
\text { The main indirect benefits mentioned are: improving relationships, trust, } \\
\text { participation and involvement in care, proximity, motivation, breaking } \\
\text { barriers, optimism, good disposition and adherence to treatment. The } \\
\text { main direct benefits mentioned were: recovery improvement, stress } \\
\text { reduction, relaxation and relief of tension, distraction, pain reduction, } \\
\text { exteriorization of feelings, adaptation mechanisms, quality of life } \\
\text { improvement, learning facilitator, reduction of anxiety. }\end{array}$ \\
\hline $\begin{array}{l}\text { Sousa \& } \\
\text { José, 2016, } \\
\text { Portugal }^{(3)} \text {. }\end{array}$ & $\begin{array}{l}26 \text { studies } \\
\text { on humor in } \\
\text { health care }\end{array}$ & $\begin{array}{l}\text { To identify the role of } \\
\text { humor in people's lives } \\
\text { and health. }\end{array}$ & SLR. & $\begin{array}{l}\text { Humor has benefits at both the organizational and health care level. } \\
\text { When using humor teams are more productive, cohesive, show less } \\
\text { stress and are more motivated and satisfied. In health and people's life } \\
\text { humor promotes well-being; helps to deal with difficult and unpleasant } \\
\text { situations, reduces tension, stress and discomfort; increases tolerance to } \\
\text { pain, and strengthen the immune system. }\end{array}$ \\
\hline $\begin{array}{l}\text { Sousa \& } \\
\text { José, 2013, } \\
\text { Portugal|(6). }\end{array}$ & $\begin{array}{l}15 \text { articles on } \\
\text { the humor } \\
\text { intervention } \\
\text { in nursing }\end{array}$ & $\begin{array}{l}\text { To characterize the } \\
\text { scientific evidence on } \\
\text { humor intervention in } \\
\text { nursing care. }\end{array}$ & $\begin{array}{l}\text { Integrative } \\
\text { Literature } \\
\text { Review } \\
\text { (ILR). }\end{array}$ & $\begin{array}{l}\text { The humor intervention is complex, since humor is paradoxical, situational, } \\
\text { multifaceted and its use has to be weighed in some situations, namely in } \\
\text { persons with cognitive impairment, mental illness and in situations of severe } \\
\text { illness. However, when a nurse makes an appropriate assessment, it seems to } \\
\text { have numerous benefits to health and well-being. } \\
\text { The use of humor facilitates communication and relationship with the cared } \\
\text { person and helps professionals deal with and overcome difficulties intrinsic to } \\
\text { their profession. }\end{array}$ \\
\hline
\end{tabular}




\begin{tabular}{|c|c|c|c|c|}
\hline $\begin{array}{l}\text { Author(s), } \\
\text { year, } \\
\text { location }\end{array}$ & Population & Aims & Methods & Results \\
\hline $\begin{array}{l}\text { Sousa et } \\
\text { al., 2016, } \\
\text { Portugal }{ }^{(21)} \text {. }\end{array}$ & $\begin{array}{l}171 \text { people } \\
\text { with chronic } \\
\text { kidney disease } \\
\text { undergoing } \\
\text { hemodialysis }\end{array}$ & $\begin{array}{l}\text { To Identify the factors } \\
\text { that influence the } \\
\text { enjoyment of humorous } \\
\text { films in people with } \\
\text { chronic kidney disease; } \\
\text { and identify the } \\
\text { humorous movies most } \\
\text { enjoyed by them during } \\
\text { hemodialysis session. }\end{array}$ & $\begin{array}{l}\text { Mixed. } \\
\text { Content } \\
\text { analysis. }\end{array}$ & $\begin{array}{l}\text { People with chronic kidney disease who enjoy humorous movies are } \\
\text { considered to be cheerful and fun. They also report to have sense of } \\
\text { humor and a fun family. In addition, they mention liking to play, to } \\
\text { laugh, to be made to laugh, to be with people with a sense of humor, to } \\
\text { listen to anecdotes, to read comic books and to listen to funny stories. } \\
\text { This study identified the sociodemographic and clinical factors related } \\
\text { to the sense of humor and that influence the appreciation of humor } \\
\text { films. It also identified the main types of humorous / humorous movies / } \\
\text { videos enjoyed by people with chronic kidney disease. This study brings } \\
\text { important contributions to the nursing intervention humor which is } \\
\text { part of the Classification of Nursing Interventions. }\end{array}$ \\
\hline $\begin{array}{l}\text { Sousa et } \\
\text { al., 2015, } \\
\text { Portugal(2). }^{(2)}\end{array}$ & 11 nurses & $\begin{array}{l}\text { To identify the meaning } \\
\text { of humor for nurses; } \\
\text { and identify the types of } \\
\text { humor used in nursing } \\
\text { practice. }\end{array}$ & $\begin{array}{l}\text { Content } \\
\text { analysis. }\end{array}$ & $\begin{array}{l}\text { Results showed that nurses identified the following manifestations of } \\
\text { humor: laughter, smile, joy, and a state of mind and well-being. The } \\
\text { types of humor found are positive/healthy and negative/unhealthy }\end{array}$ \\
\hline $\begin{array}{l}\text { Sousa et } \\
\text { al., } 2018, \\
\text { Portugal }^{(7)} \text {. }\end{array}$ & $\begin{array}{l}7 \text { articles with } \\
\text { qualitative } \\
\text { methodology }\end{array}$ & $\begin{array}{l}\text { To identify the factors } \\
\text { that influence the use of } \\
\text { humor in nursing care } \\
\text { from patient perspective }\end{array}$ & SLR. & $\begin{array}{l}\text { Factors influencing the use of humor and its benefits in nursing care } \\
\text { were identified. For nurses, humor is humanizing, generating emotions, } \\
\text { reducing tensions, improving communication and hospital experience. } \\
\text { It is influenced by gender, context, culture, self-esteem and nurses' } \\
\text { confidence. From the perspective of people with illness, humor presents } \\
\text { benefits as it generates greater participation in the therapeutic interaction }\end{array}$ \\
\hline $\begin{array}{l}\text { Tanay et al., } \\
\text { 2013, United } \\
\text { Kingdom }{ }^{(18)} \text {. }\end{array}$ & 12 articles & $\begin{array}{l}\text { To Analyze the concept } \\
\text { of humor in the } \\
\text { treatment of cancer in } \\
\text { adults. }\end{array}$ & $\begin{array}{c}\text { Content } \\
\text { analysis. } \\
\text { According } \\
\text { to the } \\
\text { Walker } \\
\text { \& Avant } \\
\text { model. }\end{array}$ & $\begin{array}{l}\text { Humor is a subjective emotional response, resulting from the } \\
\text { recognition and expression of incongruities of a comical, absurd and } \\
\text { impulsive situation, observation, character or action, which enhances } \\
\text { feelings of closeness or union when shared in the context of trust } \\
\text { between patient and nurse. It can be used as an adjustment mechanism } \\
\text { in a stressful situation, such as the cancer treatment in adults. }\end{array}$ \\
\hline $\begin{array}{l}\text { Tremayne, } \\
\text { 2014, United } \\
\text { Kingdom }{ }^{(10)} \text {. }\end{array}$ & $\begin{array}{l}\text { Articles about } \\
\text { humor }\end{array}$ & $\begin{array}{l}\text { To discuss how } \\
\text { humor can promote } \\
\text { physiological and } \\
\text { psychological well- } \\
\text { being, while reducing } \\
\text { stress and anxiety }\end{array}$ & SLR. & $\begin{array}{l}\text { The proper use of humor is a valuable resource for nursing practice. } \\
\text { When used in daily interactions with patients, humor can help develop } \\
\text { the therapeutic relationship and build resilience. Humor can promote } \\
\text { physiological and psychological well-being while reducing stress and } \\
\text { anxiety. }\end{array}$ \\
\hline
\end{tabular}

\section{Definition}

The humor concept in the treatment of cancer in adults ${ }^{(18)}$ is a subjective emotional response, resulting from the recognition and expression of incongruities of a comic, absurd, impulsive, observational or action situation. It fosters feelings of proximity or union when shared in a relationship of trust between the person in situation of illness and nurse, being able to be used in situations of stress, as, in the care of the person with cancer. This definition fits into the definition of $\mathrm{NIC}^{(5)}$ and $\mathrm{AATH}^{(4)}$ in which they humor is defined as an emotional response resulting from appreciation, recognition of incongruity, comprehension, and expression of what is funny, amusing, or comical ${ }^{(2-3,25)}$. Together with people with cognitive impairment emerging themes of humor include nonsense, sarcasm and comments on the difficulties of dementia. Laughter was identified in moments with and without humor ${ }^{(17)}$.

\section{Use and function of Humor as a nursing intervention}

In the oncology context, two studies in the UK try to show how humor is used in people with cancer. One study explains how men with a diagnosis of penile cancer use humor in relation to their diagnosis and treatment and it is noticed that their use allows them to dedramatize diagnosis and treatment and improves the therapeutic relationship with healthcare professionals ${ }^{(16)}$. In this context nurses should use humor to build the therapeutic relationship but should avoid jokes about the sexual or urinary functioning of the person with penile cancer.

In a study about the influence that laughter therapy and humor therapy have on people undergoing hemodialysis, it has been confirmed that the use of these therapies in the form of humorous videos, stories, clowns and laughter yoga have positive results in depressive states, anxiety, pain relief, immunity, fatigue, sleep quality, and other physical aspects related to respiration and blood glucose $\mathrm{e}^{(23)}$.

The use of humor in the context of care improves the experience of hospitalized patients $s^{(7,25)}$, contributing to their satisfaction, increased participation and adherence to the therapeutic regimen. Humor can play an important and even decisive role in the promotion of presence (present moment) that facilitates learning.

\section{Nursing-patient communication and improvement tool}

It is understood that both humor and laughter play a role in creating a safe social environment ${ }^{(17)}$. Another study explores the experience of four nurses using humor in their practice. It tries to understand whether there are gender differences in its use and if the humor intervention influences nurse / patient therapeutic relationship ${ }^{(15)}$. 
For nurses humor is humanizing, manages emotions, reduces tensions, and improves communication during hospitalization ${ }^{(7)}$.

\section{Factors that influence the use of humor}

Humor is influenced by personal factors such as personality, age and gender characteristics, in which men have a greater ability to use humor than women ${ }^{(3)}$.

In another study, it was found that regarding gender, women in situations of illness use humor spontaneously related to the situation they are experiencing and to relativize the situation when speaking to others ${ }^{(15)}$. Men use humor in the form of anecdotes and stories, in order to establish a balanced sense of power between nurse/patient ${ }^{(15)}$.

The circumstantial factors that influence humor are: the level of stress and perceived difficulties; duration of limitations resulting from the disease process; previous experience; ability to use verbal and non-verbal communication strategies; amount of physical symptoms and negative attitudes before illness; disease severity, pain, disability and psychic suffering; liking humor and; ability to perform executive functions $s^{(3)}$.

Factors that influence the use of humor have been identified and humor is influenced by gender, context, culture, self-esteem and the nurse's confidence ${ }^{(7)}$.

Another study was conducted people with chronic kidney disease undergoing hemodialysis ${ }^{(21)}$ and the factors that influence the appreciation of humorous films by these people were identified. It was found that people with chronic kidney disease who enjoy humorous movies consider themselves to be more cheerful and fun, report having a sense of humor, like to play and laugh, like to be with people who make them laugh and with a sense of humor, enjoy reading comic books and listening to funny anecdotes and stories.

When planning humor intervention, nurses must take these factors into account, not only in the decision to include this intervention in the care plan, but also in its construction and implementation to ensure personalized care.

\section{Activities of the humor intervention}

Another study describes the types of humor nurses identify in their practice. Nurses mentioned that humor manifests itself through laughter, smiling, joy, as a state of mind and well-being(2).

The strategies and benefits of humor intervention used in the orthopedic service in a Portuguese hospital(2) are play, slap sticking, jokes, anecdotes, puns, surprises, funny situations, personal experiences, comic comments, spontaneous comic expressions, music and movies. Laughter and humor therapy are used by people undergoing hemodialysis in the form of humorous videos, stories, clowns and laughter yoga ${ }^{(23)}$.

Intervention activities can be based on verbal and nonverbal humorous situations, images, photographs, riddles, songs, mental enigmas and riddles, and the construction of a portfolio of funny books and photographs, jokes, comedy films, cartoons, funny news stories and articles ${ }^{(3)}$.

In Portugal a doctoral research created the "mobile smile", which consisted of a car similar to medication cars, which had books, magazines, films and other humorous material that was distributed to people who were hospitalized according to their preferences ${ }^{(1)}$.

These activities are in line with the 15 activities outlined and recommended to implement the humor intervention classified in the $\mathrm{NIC}^{(5)}$.

\section{Benefits of humor in the context of health care}

For people experiencing a disease situation, humor brings benefits to the therapeutic interaction, leading to greater collaboration / participation of the sick person ${ }^{(7)}$. Nurses report that humor is an excellent working tool as it facilitates communication, humanizes care and promotes the therapeutic bond / relationship ${ }^{(7)}$.

The use of humor in nursing practice has also been a concern in the USA, as in 2008 an article ${ }^{(19)}$ emerges that seeks to evidence the benefits of using humor in a perioperative context. It concludes that humor is used to establish relationships, alleviate anxiety, release anger in a socially acceptable way, avoid or deny painful feelings and is a way to facilitate learning.

In a study conducted in the UK ${ }^{(10)}$, the author advocates using humor in nursing practice as it, helps to develop the therapeutic relationship and building resilience, promotes physical and psychological well-being, and reduces stress and anxiety.

The main indirect benefits of humor are: improving relationships, trust, participation and involvement in care, proximity, motivation, breaking barriers, optimism, good disposition and adherence to treatment. The main direct benefits mentioned were: recovery improvement, stress reduction, relaxation and relief of tension, distraction, pain reduction, exteriorization of feelings, adaptation mechanisms, quality of life improvement, learning facilitator, reduction of anxiety (22).

Another study ${ }^{(3)}$ describes the benefits of humor in organizations and health care. It shows that when using humor teams are more productive, cohesive, show less stress and are more motivated and satisfied. In health and people's life humor promotes well-being; helps to deal with difficult and unpleasant situations, reduces tension, stress and discomfort; increases tolerance to pain, and strengthen the immune system.

\section{Limitations and precautions of humor intervention}

Nurse's perceptions regarding the use of humor in the context of care indicate that humor is something very personal. What makes one person laugh, can cause discomfort and suffering in another ${ }^{(9)}$. This situation reveals the paradoxical character that humor can have ${ }^{(1)}$, that is, what is motive for humor in one person may not be for another ${ }^{(3)}$. In this sense, the use of humor must be appropriate to each situation due to the fact that it is a multifaceted phenomenon ${ }^{(1)}$.

In the UK a study demonstrates that the humor in the medical / patient interaction should be cautiously used, especially with regard to self-deprecating humor. Therefore, nurses must be prudent and use an evidence-based approach during humor intervention ${ }^{(24)}$.

Another study identifies barriers to the humor intervention in nursing practice, such as its use in inappropriate situations, the use of humor by a new or junior nurse, the impact of humor on the nurse's professionalism, personality differences and 
environmental factors ${ }^{(20)}$. These barriers may influence the nonuse of humor in nursing practice, as they may associate their use with an inadequate professional practice.

In Spain and Portugal, the importance of using humor in nursing practice has also been investigated. In Spain the applicability of humor in palliative care was studied and it was concluded that it plays an unquestionable role in this context. Nevertheless, its use still requires training and an appropriate use for each situation ${ }^{(25)}$.

The articles in Portugal show the use of humor intervention in the practice of nursing care, in different contexts. The humor intervention is complex, since humor is paradoxical, situational, multifaceted and its use must be weighed in some situations, namely in people with cognitive impairment, mental illness and in situations of severe illness. However, when nurses make an appropriate assessment, it seems to have numerous benefits to health and well-being ${ }^{(6)}$.

\section{Study limitations}

The limitations of this study are related to the exclusion of incomplete articles, abstracts and those in languages other than English, French, Portuguese and Spanish. The time horizon may also have limited the research as only articles published in the last 10 years have been included. Finally, all studies were accepted without making a quality appraisal.

\section{Contributions to the sector of nursing, health, or public policies}

This scoping review allowed us to retrieve information on humor definition; its applicability as a nursing intervention; humor as a tool to improve nurse-patient communication and relationship; influence factors; type of humor interventions; humor benefits in health care context; and limitations and precautions of humor intervention.

The results of this review may contribute to improve the planning and implementation of humor intervention in nursing care practice. It may give important contributions to the humor intervention described in $\mathrm{NIC}^{(5)}$. On the other hand, it can help in the justification of three NANDA-International ${ }^{(26)}$ diagnoses: in terms of promotion, prevention and change of sense of humor.

The synthesis of these results may boost the implementation of humor intervention in the nursing curriculum, since it describes the main indications / applications of humor, factors that influence humor, the most used activities and their benefits, as well as, the precautions to be taken within its use. On the other hand, this systematization may provide clues for future research in the context of nursing care.

The use of the scoping review methodology in this study highlights not only its contribution to the development of qualitative research, but it also evidences the practical implications of using humor as a nursing intervention, in improving the relationship and experience of patients.

\section{CONCLUSIONS}

Humor is a subjective emotional response resulting from the recognition and expression of incongruities of a comic or absurd situation.

Humor is humanizing, it allows the bettering of the experience lived in hospital context; it also allows the improvement of the communication and the trust between the nurse and the person during the process of care. On the other hand, it increases the person's participation in care.

The use of humor favors communication, which plays an important role in human interactions. It helps to promote wellbeing; dealing with difficult and unpleasant situations, reducing tension, stress and discomfort; increases tolerance to pain, and strengthens the immune system.

It is influenced by internal (personality), external and social factors. However, nurses should use it with caution, since it requires training and individualized strategies.

Humor is a complex nursing intervention, which should be used when appropriate. It deserves caution, training and adaptation to the person and must be integrated into its concrete and singular situation.

\section{REFERENCES}

1. José HM. Resposta humana ao humor: humor como resposta humana [Internet]. Loures: Lusociência; 2010[cited 2019 Mar 03]. Available from: https://www.lusodidacta.pt/enfermagem/152-resposta-humana-ao-humor-humor-como-resposta-humana

2. Sousa LM, Carvalho ML, Santos CF. Tipos de humor utilizados na prestação de cuidados pelos enfermeiros num serviço de Ortopedia. Enformação [Internet]. 2015[cited 2019 Mar 03];6:13-9. Available from: http://hdl.handle.net/10884/1015

3. Sousa LM, José HM. Benefícios do humor na saúde: revisão sistemática da literatura. Enformação [Internet]. 2016[cited 2019 Mar 03];7:22-32. Available from: http://hdl.handle.net/10884/992

4. Association for Applied and Therapeutic Humor (AATH). HOME: What is therapeutic humor? [Internet]. 2018[cited 2019 Mar 03]. Available from: https://www.aath.org/

5. Butcher HK, Bulechek GM, Dochterman JM, Wagner C. Nursing interventions classification (NIC) [Internet]. St. Louis: Elsevier Health Sciences; 2018[cited 2019 Mar 03]. Available from: https://www.elsevier.com/books/nursing-interventions-classification-nic/butcher/978-0-323-49770-1

6. Sousa LM, José HM. Revisão integrativa sobre a intervenção do humor na enfermagem. Rev Cienc Med[Internet]. 2013[cited 2019 Mar 03];9(20):307-8. Available from: http://hdl.handle.net/10884/1018

7. Sousa LM, Teixeira PM, Marques-Vieira CM, Severino SS, Faísca H, José HM. Emploi de I'humour dans la relation infirmier/personne malade: une revue de la littérature et synthèse. Rev Francoph Int Rech Infirm[Internet]. 2018[cited 2019 Mar 03];4(1):30-8. Available from: https://doi. org/10.1016/j.refiri.2017.07.011 
8. International Council of Nurses (ICN). CIPE: Classificação Internacional para a Prática de Enfermagem: versão 2015[Internet]. Loures: Lusoditacta; 2016[cited 2019 Mar 03]. Available from: https://futurosenf.files.wordpress.com/2017/04/cipe_2015.pdf

9. Haydon G, Riet PV. A narrative inquiry: how do nurses respond to patients' use of humor?. Contemp Nurse[Internet]. 2014 [cited 2019 Mar 03];46(2):197-205. Available from: https://doi.org/10.5172/conu.2014.46.2.197

10. Tremayne P. Using humor to enhance the nurse-patient relationship. Nurs Stand[Internet]. 2014[cited 2019 Mar 03];28(30):37-40. Available from: https://doi.org/10.7748/ns2014.03.28.30.37.e8412

11. Arksey H, O'Malley L. Scoping studies: towards a methodological framework. Int J Soc Res Methodol[Internet]. 2005 [cited 2019 Mar 03];8(1):19-32. Available from: https://doi.org/10.1080/1364557032000119616

12. Sousa LM, Marques JM, Firmino CF, Frade F, Valentim OS, Antunes AV. Modelos de formulação da questão de investigação na Prática Baseada na Evidência. Rev Inv Enferm[Internet]. 2018[cited 2019 Mar 03];S2(23):31-9. Available from: http://hdl.handle. net/20.500.12253/1287

13. Preferred Reporting Items for Systematic Reviews and Meta-Analyses (PRISMA). Welcome to the Preferred Reporting Items for Systematic Reviews and Meta-Analyses (PRISMA) website! [Internet]. 2015[cited 2019 Mar 03]. Available from: www.prisma-statement.org

14. Sousa LM, Marques-Vieira C, Severino SS, Antunes AV. Metodologia de Revisão Integrativa da Literatura em Enfermagem. Rev Inv Enferm[Internet]. 2017[cited 2019 Mar 03];S2(21):17-26. Available from: http://hdl.handle.net/20.500.12253/1311

15. Haydon G, van der Reit P, Browne G. A narrative inquiry: humor and gender differences in the therapeutic relationship between nurses and their patients. Contemp Nurse[Internet]. 2015[cited 2019 Mar 03];50(2-3):214-26. Available from: https://doi.org/10.1080/10376178.2015.1021436

16. Branney P, Witty K, Braybrook D, Bullen K, White A, Eardley I. Masculinities, humour and care for penile cancer: a qualitative study. J Adv Nurs[Internet]. 2014 [cited 2019 Mar 03];70(9):2051-60. Available from: https://doi.org/10.1111/jan.12363

17. Liptak A, Tate J, Flatt J, Oakley MA, Lingler J. Humor and laughter in persons with cognitive impairment and their caregivers. J Holist Nurs[Internet]. 2014 [cited 2019 Mar 03];32(1):25-34. . Available from: https://doi.org/10.1177/0898010113500075

18. Tanay MA, Roberts J, Ream E. Humor in adult cancer care: a concept analysis. J Adv Nurs[Internet]. 2013 [cited 2019 Mar 03];69(9):2131-40. Available from: https://doi.org/10.1111/jan.12059

19. Buxman K. Humor in the OR: a stitch in time? AORN J[Internet]. 2008 [cited 2019 Mar 03];88(1):67-77. Available from: https://doi. org/10.1016/j.aorn.2008.01.004

20. Jones $P$, Tanay MA. Perceptions of nurses about potential barriers to the use of humor in practice: a literature review of qualitative research. Contemp Nurse [Internet]. 2016 [cited 2019 Mar 03];52(1):106-18. Available from: https://doi.org/10.1080/10376178.2016.1198235

21. Sousa LM, Marques-Vieira C, Severino S, Pozo Rosado JL, José HM. Fatores explicativos da apreciação de filmes cómicos em pessoas com doença renal crónica. Rev Inv Enferm[Internet]. 2016[cited 2019 Mar 03];S2(15):49-55. Available from: http://hdl.handle.net/10400.17/2622

22. Santos CF, Sousa LM, Carvalho ML, Severino SS, José HM. A intervenção Humor em enfermagem num serviço de ortopedia: estratégias e benefícios. Rev Inv Enferm[Internet]. 2016[cited 2019 Mar 03];S2(16):36-44. Available from: http://hdl.handle.net/10400.17/2623

23. Bennett PN, Parsons T, Ben-Moshe R, Weinberg M, Neal M, Gilbert K, et al. Laughter and humor therapy in dialysis. Semin Dial[Internet]. 2014 [cited 2019 Mar 03];27(5):488-93. Available from: https://doi.org/10.1111/sdi.12194

24. McCreaddie $M$, Wiggins $S$. The purpose and function of humor in health, health care and nursing: a narrative review. J Adv Nurs[Internet]. 2008 [cited 2019 Mar 03];61(6):584-95. Available from: https://doi.org/10.1111/j.1365-2648.2007.04548.x

25. Pinna MÁ, Mahtani-Chugani V, Sánchez Correas MÁ, Sanz Rubiales A. The use of humor in palliative care: a systematic literature review. Am J Hosp Palliat Med[Internet]. 2018 [cited 2019 Mar 03];1:1049909118764414. Available from: https://doi.org/10.1177/1049909118764414

26. Herdman TH, Kamitsuru S, (Eds.). NANDA International - Nursing Diagnoses: Definitions and classification 2018-2018. Eleventh Edition. New York: Thieme; 2018. 